\title{
A SYSTEM DYNAMICS MODEL TO IDENTIFY THE IMPACT OF THE ECONOMIC CRISIS ON CRIME RATE AND ON SECURITY SENSATION IN EUROPEAN SOCIETIES
}

\author{
Author(s) / Auteur(s) : \\ Nikolaos ZOANNOS \\ University of Piraeus, Hellenic Society for Systemic Studies (HSSS) \\ nmzoanno@gmail.com \\ Rallis ANTONIADIS \\ University of Piraeus, Hellenic Society for Systemic Studies (HSSS) \\ arisantoniadis@gmail.com \\ Prof. Nikitas ASSIMAKOPOULOS \\ University of Piraeus, Hellenic Society for Systemic Studies (HSSS) \\ assinik@unipi.gr
}

\begin{abstract}
Résumé :
Modern society is a Complicated System, in which the interaction between its essential parts is affected in a daily basis by: (a) the Economic Crisis, (b) the Feeling of Xenophobia, (c) the Interweaving of the Political System and $(d)$ the Degeneration of Human Interpersonal Relationships. Two important facts that have been excessively observed in the European Union over the last few years are the increase of Crime Rate, and at the same time the decrease of Security Sensation. The model that we have developed simulates the way that particular social phenomena such as: (a) the taxation, $(b)$ the reduction of the State Expenditure on Equipment and (c) the conflicts of interest caused by the Economic Crisis, affect the Crime Rate. Therefore, this study can be the starting point for identifying other social phenomena that should be taken into account in the Strategic Plan of Crime and Violence treatment in member countries of the European Union.
\end{abstract}

\section{Keywords / Mots-clés :}

System Dynamics Model, Modeling, Economic Crisis, Feeling of Xenophobia, Interweaving of the Political System, Degeneration of Human Interpersonal Relationships, Security Sensation, European Socities.

\section{INTRODUCTION}

Let's consider the European Union as a "System" and the country members not only as "Subsystems" of it, but also as Systems interconnected to each other. The behavior of a Subsystem emerges as a result of the interactions or relations between its elements (Senge, 2006). The basic - important element for each Subsystem is its citizens. If the relations between those citizens are armonic then the behavior of the Subsystem is being led to Balance, otherwise the behavior of the Subsystem is being led to "Mess" and it deffects the behaviour of the "whole" (Rosalind Armson, 2011).

The behavior of each citizen consists of a variable which is affected by multiple factors. For example, high "taxation" affects human psychology which is usually expressed with disappointment, and in same cases with anger from the institutions' part. The "unemployment" is a phenomenon that is strongly observed in modern societies and can also affect human behavior. In some European countries facing economic crisis, political corruption along with bribery and violation of moral and legal institutions has been explicitly observed. Events that are a catalyst for the harmonious relationship between the Subsystem elements. One other basic factor is the geopolitical position of a country, because if it inside the borders of the European Union, then we observe a high rate of 
immigration which increases the locals' Feeling of Xenophobia. In this cases we have also observed increase in the Crime Rate and decrease of the Security Sensation.

There are a lot of factors that must be studied and due to the nature of this factors we are going to call them as "Social Variables". The Model that we have developed in VenSim Software has as its purpose the identification of the way in which the Crime Rate and the Security Sensation are being affected. The conclusions that will be derived from this study can help on the development of a more efficient Strategic Plan on the Crime and Violence treatment.

\section{SYSTEMIC BACKGROUND}

\section{System, Structure, Environment and Systems' Purpose}

As we have already seen a "System" can be defined as "a set of elements in interaction" (Bertalanffy, 1968) or as "a set of entities with relations between them" (Langefors, 1995). Systems' approach can be considered as a means to deal with complex problematic situations or as a management practice. According to that, given a certain objective in a very complex network of interactions, the System Specialist(s) tries to find ways and means for its realization considering alternative solutions and choosing those promising optimization at maximum efficiency and minimum cost (Bertalanffy, 1968). So, in order to limit our study we will consider as a "System" a specific Greek Organization, "Ministry of Civil Protection", which interacts with other Greek Organizations, in order to promote social prosperity, citizens' safety and harmonious coexistence within the European Union (Figure 1).

\section{Greek Public Organizations}

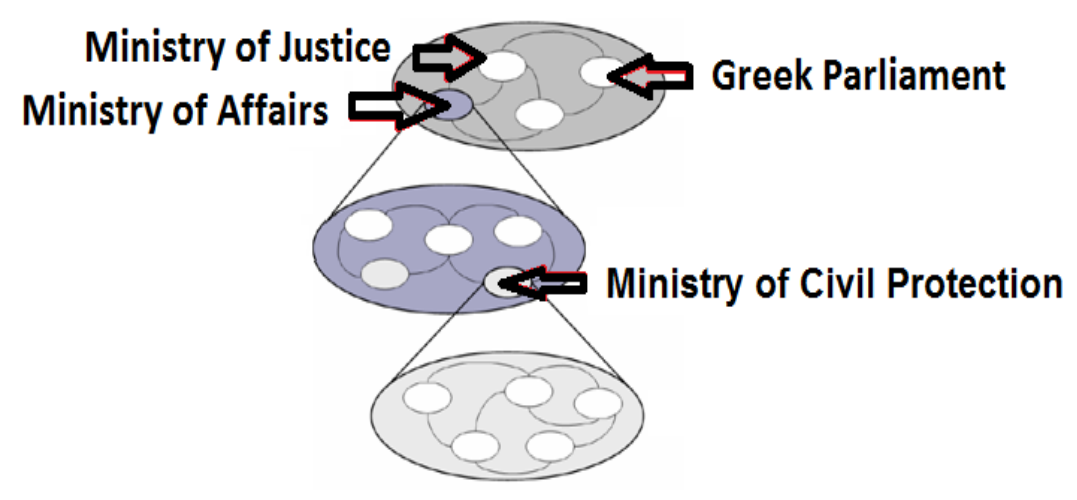

Figure 1. Greek Public Organizations

The System's Purpose is called "Mission" and it is foreseen by Greek Law 1481/1-10-1984, Government Gazette A-152 and Law 2800/2000". Although the mission is well defined, nowadays we can trace that the System doesn't achieve its purpose. This problematic situation is very difficult to be studied due to the fact that there are a lot of variables (socio-economic) that are out of the Systems' Control (Systems' environment) and they nevertheless alter the Systems' behavior. There are two (2) basic methods that can be used in order to study a problematic situation: (1) Critical thinking and (2) Systems thinking (Heinberg, 2018).

An alternative method is to identify the "whole", of which the System under study is an integral part, in order to understand the behavior of this System. The study of this behavior over time leads to the identification of the Structure governing the essential parts of the System, and thus a Mental Model can be defined. 


\section{Systems' Thinking and System Dynamics}

When we are studying a System, we are using terms that are well defined in order for our conclusions to be governed by academic robustness. So the term "System Dynamics" is a methodology which helps us not only to gradually understand the behavior of complex Systems, but also to trace if any Feedback Loops may exist. "Methodology" means a well-organized set of processes, techniques, tools, software and documentation that will help us in Modeling the System under study (where "Model" defines the visualization of a System in order to determine its behavior progressively, and if possible to predict its future behavior).

As we have allready mentioned, System Dynamics is a well defined methodology which contains an infinite loop of five (5) basic steps:

- Tracing the Problem

- Developing a Dynamic Hypothesis

- Formulation

- Testing the Mental Model

- Policy Formulation \& Evaluation

At step one (1) the Systemic Analyst has to trace the nature of the problem. The problem in our study is the increase of Crime Rate in Greece and at the same time the reduction of Security Sensation for the formulation. Although there are tree (3) different ways: (1) Systemic Dynamics - SD , (2) Discrete Event Modeling - DE and (3) Agent Based Modeling - AB, we have chosen Systemic Dynamic because the study of social facts and emotions is usually approached abstractively.

\section{Status Quo \& Dynamic Hypothesis}

In our study we will focus only on burglaries and thefts, crimes with penalty from six (6) months up to two (2) years, because those are the most common types of crimes that are being committed nowadays. By studying the statistics of both the Greek Police (Ministry of Civil Protection, 2018) and other sources (Georgakopoulos.org, 2018), we observe that in Athens in the year 2017 were committed a total of 63,429 Thefts and Burglaries, compared to 59,586 which have been committed in the year 2016. Accordingly, studying the data for the second biggest town in Greece, Thessaloniki, we find that a total of 16,876 thefts and burglaries were committed in 2017, compared to the 14,595 which have been commited in 2016. From all the above data, it appears that in the year 2017, a total of 80,305 thefts and burglaries took place, while in 2016 there were only 74,181. Those numbers are translated into 8\% increase of Crime Rate for 2017.

In Greece, the total prisons' capacity is at about 9.886 prisoners, and in 2017 there was a decrease from 121.4 prisoners to 97 prisoners per 100 seats. This specific decrease is due to the elasticity of convictions, concerning the commission of offenses, the penalty of which does not exceed 24 months. The convertion of those numbers gives us a $\mathbf{7 5 \%}$ increase of justice elasticity. On the other hand the Economic Crisis and the loans that Greece has taken from the International Monetary Fund (IMF) led to the increase of direct taxes (Law 4093/2012 \& 4354/2015) which brought a 30\% reduction of gross wage for public officials (Dikaiologitika news, 2017 - Taxheaven article, 2013). The Economic

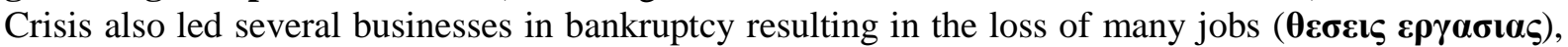
which forced the unemployment rate to go through the roof up to $20.6 \%$ (Greek Statistical Authority, 2018). One other catalyst factor is the increase of Immigration (Eurostat, 2016) which has been found at about $8 \%$, divided in $6 \%$ for citizens of non-member countries and $2 \%$ for citizens of other EU Member States. The Feeling Increase of Xenophobia was inevitable and combined with all the previous data has led not only to a decrease in trust towards the Public Authorities, but also to the increase of Crime Rate.

At this point we are capable to develop our Dynamic Hypothesis which predicts that the increase of Crime Rate is directly linked to "Social Variables". We also dare to predict that the most detrimental 
factor is the unemployment, and if it is combined with other social variables can rapidly lead to the increase of Crime Rate.

\section{Causal Loop Diagrams}

In order to be able to design a Mental Model that reduces complexity at the same time with its execution, we have to develop Causal loop Diagrams which will map the relationships between different variables, while determining whether the dependence between them is proportional (so we are led to Disorder) or vice versa (so we are led to Balance), and therefore we will be able to trace phenomena similar to those in reality,. We begin by determining that the more the number of "Patrols" (each patrol is made up of two police officers) increases, the more possible it is to trace a crime while is being committed. In an inversely proportional manner, as crime rate decreases, the security sense of citizens will grow (Figure 2).

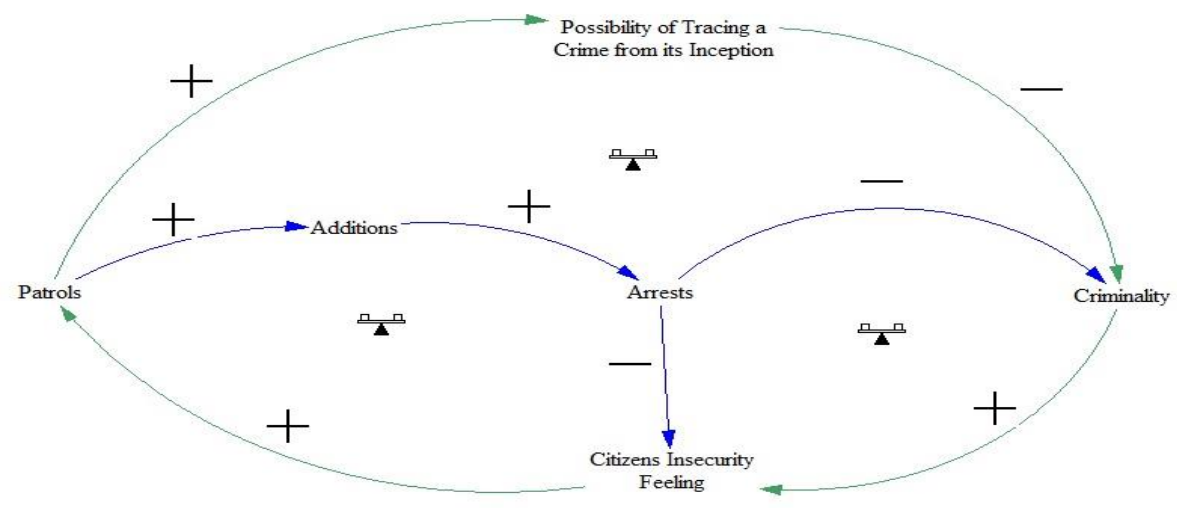

Figure 2. Causal loop Diagram for Patrols

We continue by specifying that with the growth in numbers of the arrests being made and given that the number of cells in Greek prisons is predetermined and trivial, we notice that the Justice System must be elastic so that only the perpetrators of very serious offenses will be prisoned. (at this point we have assumed that there must always be a safety gap of 3\% of empty cells in prisons). This elasticity affects Criminality and as a result the decisions made are more flexible, causing the security sense of citizens to be eliminated, and at the same time the trust in the Public Authorities to worn out (Figure $3)$.

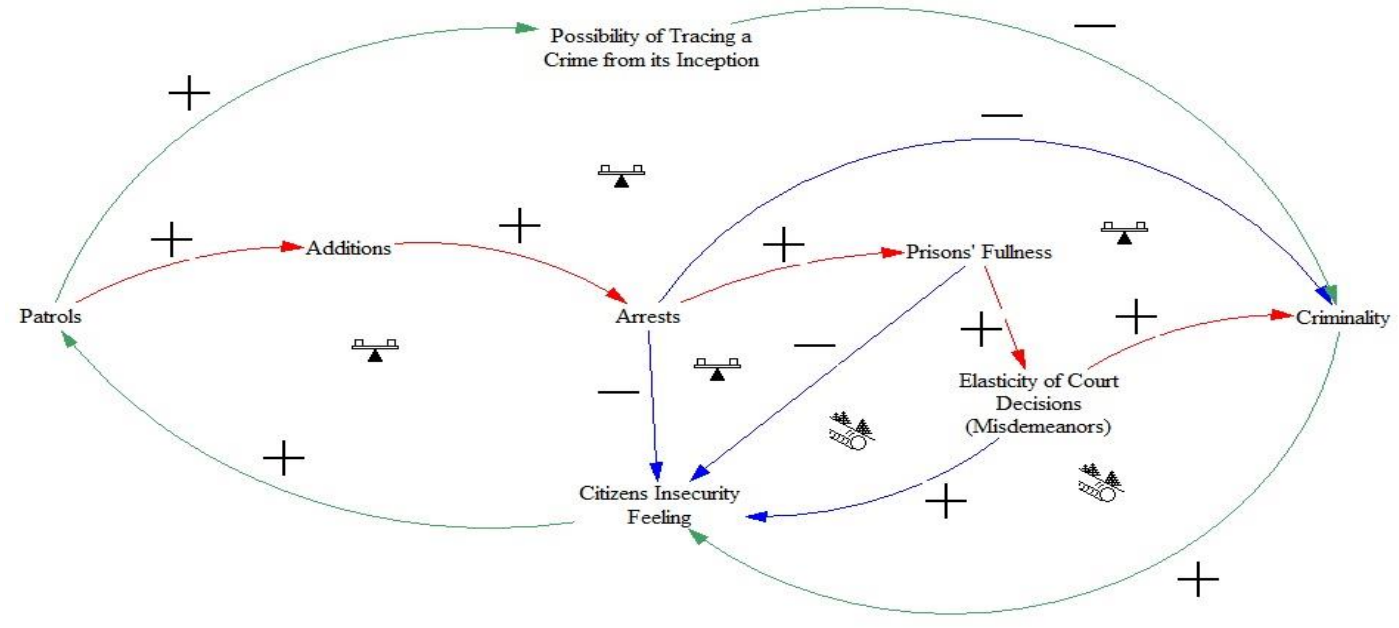

Figure 3. Causal loop Diagram for Justice Elasticity 
If in the last diagram we combine all the other Social Variables (Immigation, Feeling of Xenophobia, Taxation, Unemployment, Political Corruption, Public Expenditure etc), tracking also the connections between them and the loops that may occure, then we can develop a more complex Casual Loop Diagram which will consist of the base of our Mental Model and will present the Problem at its real dimensions (Figure 4).

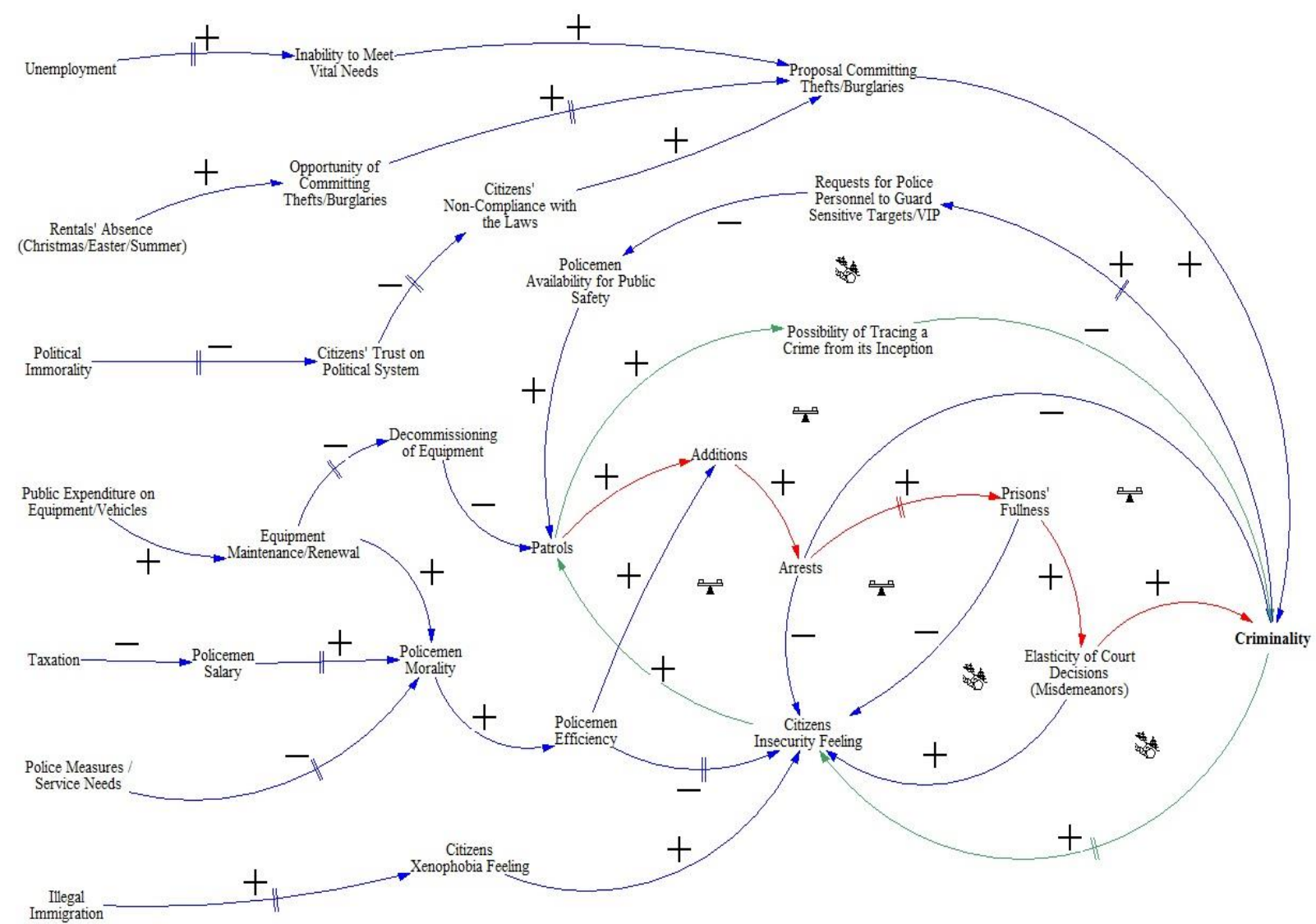

Figure 4. Causal Loop Diagram for Social Variables

Note: In the above Casual Loop Diagram, intermediate variables have been used, although there are not necessary, just to explain as detailed as possible, the way of our thinking.

\section{Model Views, Variables and Equations}

To identify the impact of Economic Crisis in Crime Rate, we have to devide our study in different "Views", so as to reduce complexity. There are a total of 5 Views, which should be studied in the order listed below:

- Calculate Number of Patrols

- Financial Annual Budget

- Calculate Policemen Efficiency

- Calculate Arrests \& Imprisonments

- Calculate Proposal Committing Thefts/Burglaries

In View "Calculate Number of Patrols" (Figure 5) the analyst has to determine the variables "Available Functionally Cars" and "Malfunctioned Cars",as well as the variable "Amount of Available Cars" to be calculated. After that, the ammount of policemen that have been ordered for:

- Sports/Demonstartions (per month) 
- Sensitive Targets (VIP)

- Permanent Department Staff

must be defined.

At this point the model will calculate the price of the variable "Policemen Available for Patrols", and at the same time the price of the variable "Patrols" will be calculated, considering the fact that every Patrol needs two (2) policemen (Table 1).

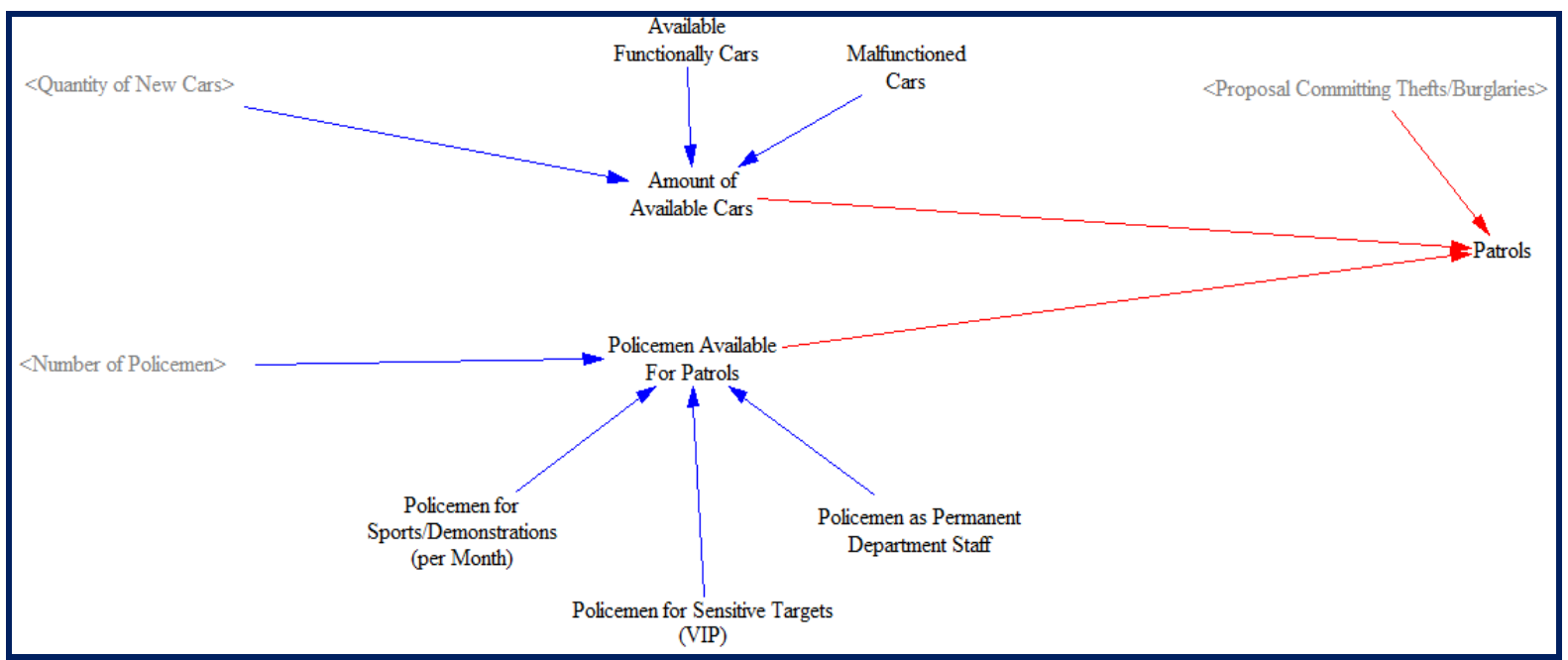

Figure 5. View "Calculate Number of Patrols"

The next View is the "Financial Annual Budget" (Figure 6) where the analyst must initiate the price of the variable "Initial Budget" and then he must define the variable "Aver Monthly Internal Management" which describes the monthly cost for rents, stationery etc. Also the variable "Aver Salary" must be defined according to the law that we have already mentioned. The next step is to determine whether there is a need of new cars (variable "Quantity of New Cars"), and if so what is the aver value of those cars (variable "Aver Price"). The value of the shadow variables is automatically calculated and when the "Aver Distance" variable is defined then the model will simulate the way that the annual budget is going to be spent (Table 1).

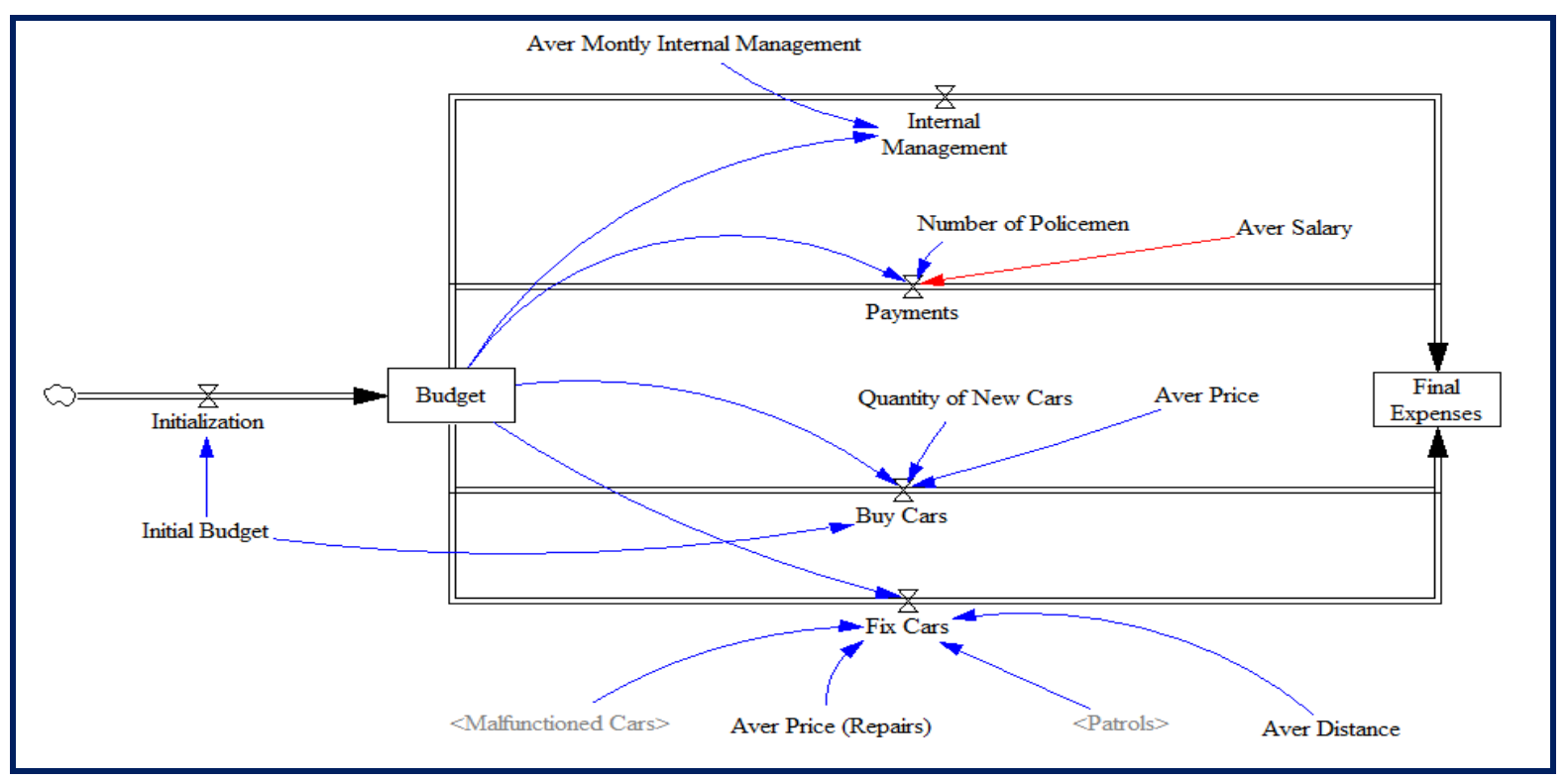

Figure 6. View "Financial Annual Budget" 
The value of variable "Aver Salary" is going to be used as a shadow variable on view "Calculate Policemen Efficiency" (Figure 7). The analyst must set the value of variable "Salary Taxation" (Direct Taxes) for a policeman, according to the Greek Laws, and then the variable "Husband Salary" must also be set. The monthy expenses of a Greek family, a Greek policeman and his/her spouse with two (2) kids at the age of 7 to 18 years old, are going to be calculated when the analyst assigns the values of the variables: (1) Bills, (2) Tickets/Fuel, (3) Super Market Cost, (4) Rent/Loan (etc), (5) Extracuriccular Activities, (6) Entertainment, (7) Car Service/ Insurance and (8) Personal Expenses. At this point of our study we have a visa, that the greek average family has managed to put away the amount of $1500 €$. Our model is going to add or deduct the money from the bank account according to the monthly expenses, so as to constitute a possitive or a negative phycological factor on policemans' efficency (Table 1). We have also used a combination of "Pulse Train" with "Random Uniform" equations in order for our model to co-integrate factors that are actually observed, aiming for the final results, after every possible alternative is used, to be within the statistical error of $5 \%$.

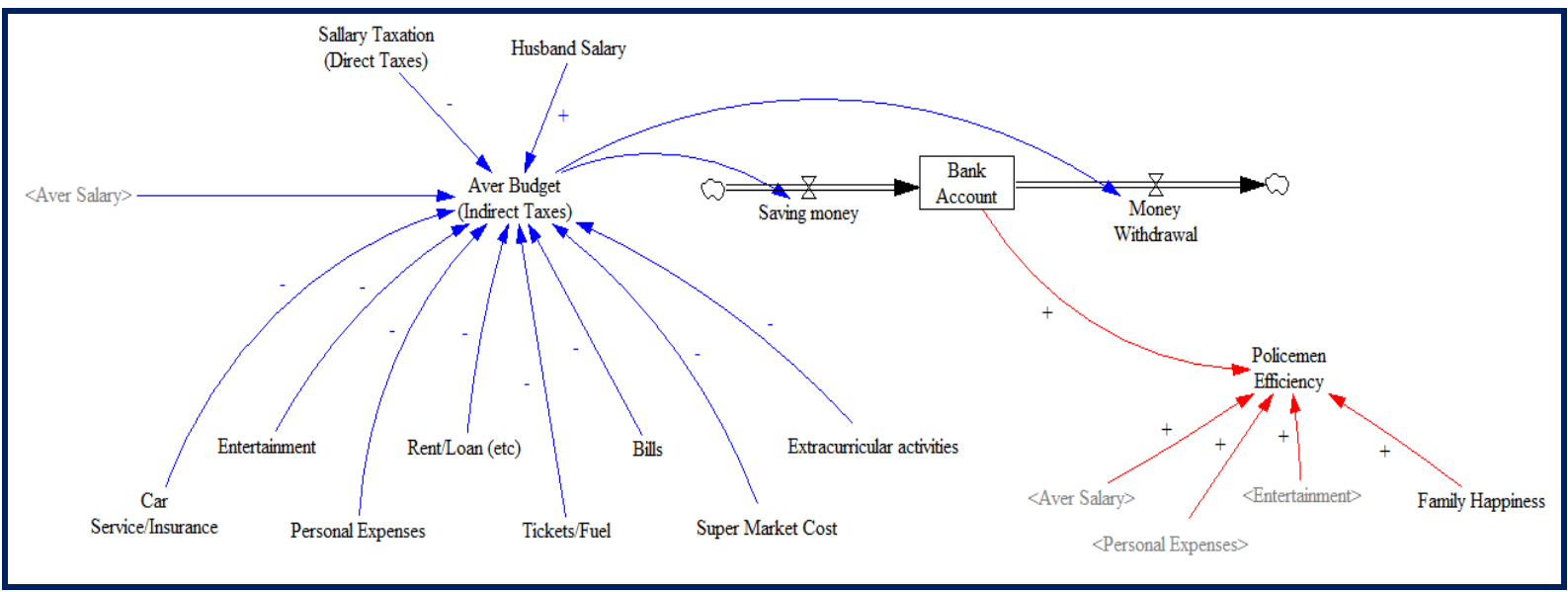

Figure 7. View "Calculate Policemen Efficiency"

The next view is "Calculate Arrests \& Imprisonments" (Figure 8). The variable "Possible Additions" determines the ability of a patrol (with two policemen), either to locate a crime at the time it is committed, or to locate people who are wanted or who are suspects. By initiating the values of variables "Prisoners Nowadays" and "Prisons Final Capacity" the model will calculate the value for the variable "Empty Seats in Prisons". This value is going to be combined with the variable "Other Factors" which contains a "Random Uniform" equation in order to estimate the possible average phychological condition of Greek Judges (Table 1).

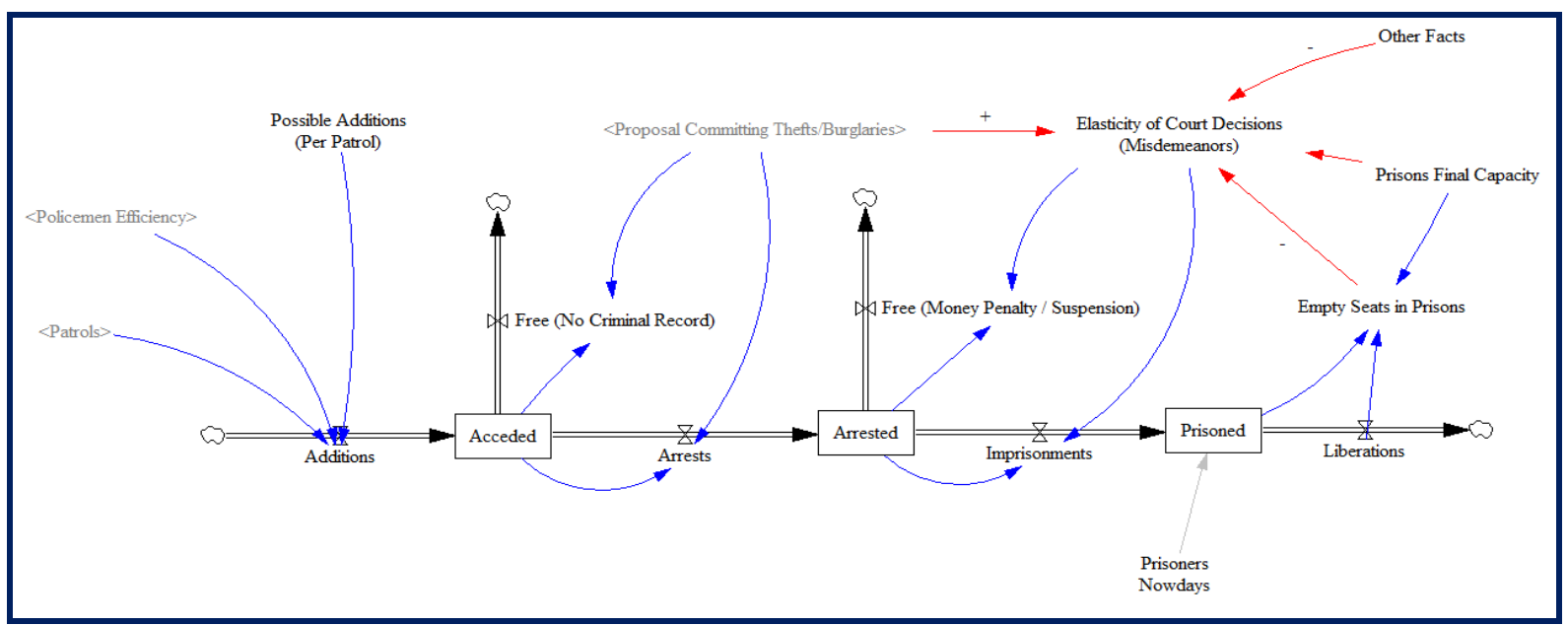

Figure 8. View "Calculate Arrests \& Imprisonments" 
The analyst at this point, has to go on the next view "Calculate Proposal Commiting Thefts/Burglaries" (Figure 9) so as to initiate the value of variables: (1) Illegal Immigration, (2) Unemployment and (3) Political Immorality. Those values are going to be combined with the value of the variable "Sudden Events - Holidays" (which is a Pulse Train and a Random Uniform Equation which simulates the ammount of people that are not in their houses). The model is going to calculate the value of variable "Proposal Commiting Thefts/Burglaries" which transfers its price as a shadow variable on view "Calculate Arrests \& Imprisonments" with the aim of making a correct calculation of variable "Elasticity of Court Decisions (Misdemeanors)".

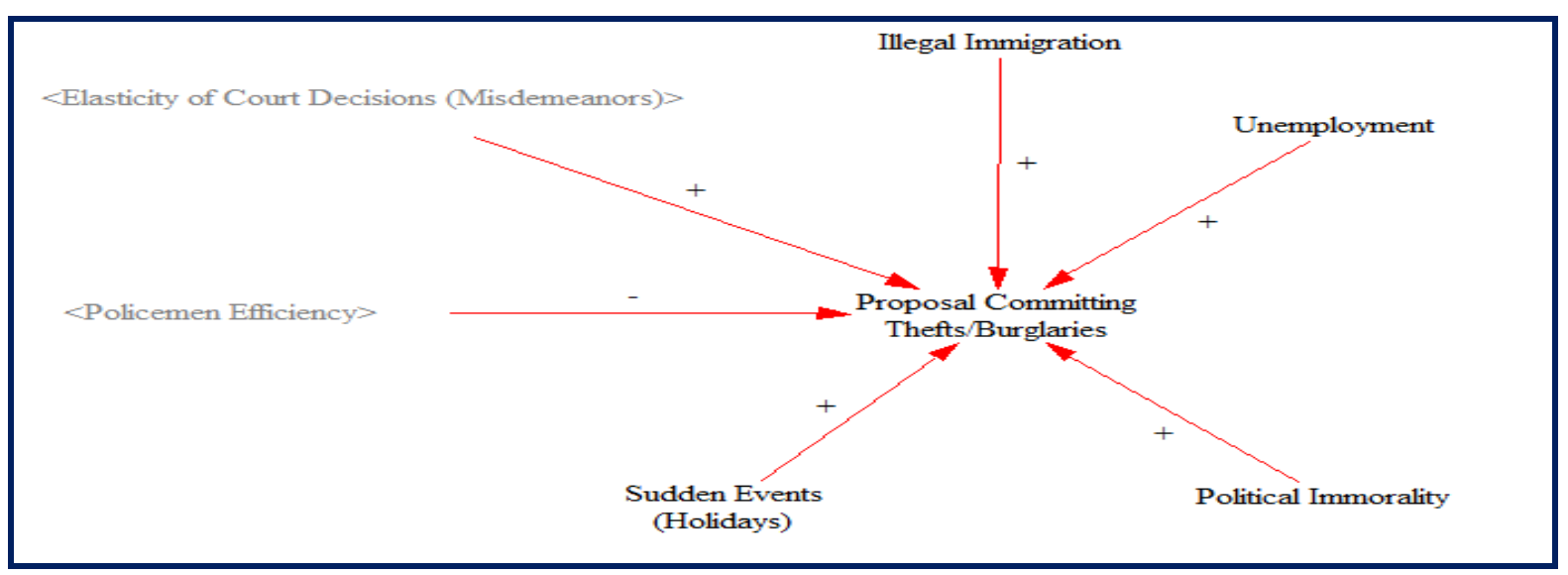

Figure 9. View "Calculate Proposal Commiting Thefts/Burglaries"

The value of variable "Elasticity of Court Decisions (Misdemeanors)" will affect retrospectively the value of the variable "Calculate Proposal Commiting Thefts/Burglaries" (Table 1).

Table 1. Variables \& Stocks Equations

\begin{tabular}{|c|c|}
\hline No & Equations \\
\hline \multirow[t]{2}{*}{1} & Acceded= INTEG (Additions-Arrests-"Free (No Criminal Record)",Additions) \\
\hline & Units: **undefined $* *$ \\
\hline \multirow[t]{2}{*}{2} & Additions $=(($ Possible Additions (Per Patrol)"*3)*(Patrols*Policemen Efficiency) $) / 12$ \\
\hline & Units: $* *$ undefined $* *$ \\
\hline \multirow[t]{2}{*}{3} & $\begin{array}{l}\text { Amount of Available Cars=IF THEN ELSE(Available Functionally Cars+Quantity of } \\
\text { New Cars-Malfunctioned Cars >0,Available Functionally Cars+Quantity of New Cars- } \\
\text { Malfunctioned Cars,0) }\end{array}$ \\
\hline & Units: **undefined $* *$ \\
\hline \multirow[t]{2}{*}{4} & Arrested= INTEG (Arrests-"Free (Money Penalty / Suspension)"-Imprisonments,Arrests) \\
\hline & Units: $* *$ undefined $* *$ \\
\hline \multirow[t]{2}{*}{5} & Arrests=Acceded*"Proposal Committing Thefts/Burglaries" \\
\hline & Units: $* *$ undefined $* *[0,10000,1]$ \\
\hline 6 & Available Functionally Cars $=0$ \\
\hline & Units: **undefined $* *[0,10000,1]$ \\
\hline
\end{tabular}




\begin{tabular}{|c|c|}
\hline \multirow[t]{2}{*}{7} & $\begin{array}{l}\text { Aver Budget (Indirect Taxes)=(Aver Salary-Aver Salary*"Salary Taxation (Direct } \\
\text { Taxes)"+Husband Salary)-Bills-Extracurricular activities-Entertainment-Personal Expenses } \\
\text {-"Rent/Loan (etc)" }\end{array}$ \\
\hline & Units: **undefined $* *$ \\
\hline \multirow[t]{2}{*}{8} & Aver Distance $=0$ \\
\hline & Units: $* *$ undefined $* *[0,300,10]$ \\
\hline \multirow[t]{2}{*}{9} & Aver Montly Internal Management $=0$ \\
\hline & Units: $* *$ undefined $* *[10000,200000,1000]$ \\
\hline \multirow[t]{2}{*}{10} & Aver Price $=8000$ \\
\hline & Units: **undefined $* *[8000,25000,100]$ \\
\hline \multirow[t]{2}{*}{11} & Aver Price $($ Repairs $)=0$ \\
\hline & Units: $* *$ undefined $* *[20,1500,10]$ \\
\hline \multirow[t]{2}{*}{12} & Aver Salary $=1200$ \\
\hline & Units: **undefined $* *[1000,2300,10]$ \\
\hline \multirow[t]{2}{*}{13} & Bank Account= INTEG (Saving money-Money Withdrawal,1500) \\
\hline & Units: **undefined $* *$ \\
\hline \multirow[t]{2}{*}{14} & Bills=50+PULSE TRAIN $(1,1,2,12) *$ RANDOM UNIFORM $(100,300,1)$ \\
\hline & Units: **undefined $* *$ \\
\hline \multirow[t]{2}{*}{15} & Budget $=$ INTEG (-(Buy Cars+Fix Cars+Internal Management+Payments),Initialization) \\
\hline & Units: **undefined ${ }^{* *}$ \\
\hline \multirow[t]{2}{*}{16} & Buy Cars=IF THEN ELSE(Initial Budget=Budget, Quantity of New Cars*Aver Price , 0) \\
\hline & Units: $* *$ undefined $* *$ \\
\hline \multirow[t]{2}{*}{17} & $\begin{array}{l}\text { Car Service/Insurance }=35+\text { PULSE TRAIN }(1,0.5,6,12) * \text { RANDOM UNIFORM }(10 \text {, } \\
270+240-50,1)\end{array}$ \\
\hline & Units: **undefined $* *[0,1000,10]$ \\
\hline \multirow[t]{2}{*}{18} & $\begin{array}{l}\text { Elasticity of Court Decisions (Misdemeanors)= IF THEN ELSE(1-("Proposal } \\
\text { Committing Thefts/Burglaries" *0.3+(Empty Seats in Prisons/Prisons Final } \\
\text { Capacity)*0.5+Other Facts*0.2)>=0.8, 0.8, } 1 \text {-("Proposal Committing } \\
\text { Thefts/Burglaries"*0.3+(Empty Seats in Prisons/Prisons Final Capacity)*0.5+Other } \\
\text { Facts*0.2) ) }\end{array}$ \\
\hline & Units: $* *$ undefined $* *[0,1]$ \\
\hline \multirow[t]{2}{*}{19} & Empty Seats in Prisons=Prisons Final Capacity-Prisoned+Liberations \\
\hline & Units: **undefined $* *$ \\
\hline \multirow[t]{2}{*}{20} & Entertainment $=10$ \\
\hline & Units: $* *$ undefined $* *[10,400,10]$ \\
\hline 21 & Extracurricular activities $=0$ \\
\hline
\end{tabular}




\begin{tabular}{|c|c|}
\hline & Units: **undefined $* *[0,500,10]$ \\
\hline \multirow[t]{2}{*}{22} & $\begin{array}{l}\text { Family Happiness }=0.01+\text { PULSE TRAIN }(1,2 / 365,5 / 365,12) * \text { RANDOM UNIFORM }( \\
0.01,0.99,1)\end{array}$ \\
\hline & Units: **undefined** \\
\hline \multirow[t]{2}{*}{23} & Final Expenses= INTEG $($ Buy Cars+Fix Cars+Internal Management + Payments, 0$)$ \\
\hline & Units: **undefined** \\
\hline \multirow[t]{3}{*}{24} & FINAL TIME $=12$ \\
\hline & Units: Day \\
\hline & The final time for the simulation. \\
\hline \multirow[t]{2}{*}{25} & $\begin{array}{l}\text { Fix Cars=IF THEN ELSE(Budget-(Patrols*Aver Distance*12.3*30)-(Malfunctioned } \\
\text { Cars*"Aver Price (Repairs)")>=0, (Patrols*Aver Distance*12.3*30)+(Malfunctioned } \\
\text { Cars*"Aver Price (Repairs)"),0) }\end{array}$ \\
\hline & Units: $* *$ undefined $* *$ \\
\hline \multirow[t]{2}{*}{26} & $\begin{array}{l}\text { Free (Money Penalty / Suspension)=Arrested*"Elasticity of Court Decisions } \\
\text { (Misdemeanors)" }\end{array}$ \\
\hline & Units: **undefined $* *$ \\
\hline \multirow[t]{2}{*}{27} & Free (No Criminal Record)=Acceded*(1-"Proposal Committing Thefts/Burglaries") \\
\hline & Units: $* *$ undefined $* *$ \\
\hline \multirow[t]{2}{*}{28} & Husband Salary $=750$ \\
\hline & Units: **undefined $* *[0,2000,10]$ \\
\hline \multirow[t]{2}{*}{29} & Illegal Immigration $=0.08$ \\
\hline & Units: **undefined $* *[0.05,0.45,0.01]$ \\
\hline \multirow[t]{2}{*}{30} & $\begin{array}{l}\text { Imprisonments=IF THEN ELSE(Arrested*(1-"Elasticity of Court Decisions } \\
\text { (Misdemeanors)")>=0,Arrested*(1-"Elasticity of Court Decisions (Misdemeanors)"),0) }\end{array}$ \\
\hline & Units: **undefined ${ }^{* *}$ \\
\hline \multirow[t]{2}{*}{31} & Initial Budget $=1000000000$ \\
\hline & Units: $* *$ undefined $* *[1 \mathrm{e}+009,5.5 \mathrm{e}+009,100000]$ \\
\hline \multirow[t]{3}{*}{32} & INITIAL TIME $=1$ \\
\hline & Units: Month \\
\hline & The initial time for the simulation. \\
\hline \multirow[t]{2}{*}{33} & Initialization=Initial Budget \\
\hline & Units: **undefined $* *$ \\
\hline \multirow[t]{2}{*}{34} & $\begin{array}{l}\text { Internal Management=IF THEN ELSE(Budget-Aver Montly Internal Management }>=0 \text {, } \\
\text { Aver Montly Internal Management,0) }\end{array}$ \\
\hline & Units: **undefined $* *$ \\
\hline 35 & Liberations $=0.3+\mathrm{PULSE}$ TRAIN $(1,1,1,12) * \mathrm{RANDOM} \operatorname{UNIFORM}(1,10,1)$ \\
\hline
\end{tabular}




\begin{tabular}{|c|c|}
\hline & Units: **undefined $* *$ \\
\hline \multirow[t]{2}{*}{36} & Malfunctioned Cars $=0$ \\
\hline & Units: $* *$ undefined $* *[0,5000,1]$ \\
\hline \multirow[t]{2}{*}{37} & $\begin{array}{l}\text { Money Withdrawal=IF THEN ELSE("Aver Budget (Indirect Taxes)" }<0,-" \text { Aver Budget } \\
\text { (Indirect Taxes)",0 ) }\end{array}$ \\
\hline & Units: **undefined $* *$ \\
\hline \multirow[t]{2}{*}{38} & Number of Policemen $=30000$ \\
\hline & Units: **undefined $* *[1,60000,1]$ \\
\hline \multirow[t]{2}{*}{39} & Other Facts=RANDOM UNIFORM $(0.1,0.9,0.125)$ \\
\hline & Units: $* *$ undefined $* *$ \\
\hline \multirow[t]{2}{*}{40} & $\begin{array}{l}\text { Patrols=IF THEN ELSE((Policemen Available For Patrols/2)>=Amount of Available } \\
\text { Cars, Amount of Available Cars, (Policemen Available For Patrols/2)*"Proposal } \\
\text { Committing Thefts/Burglaries"*3) }\end{array}$ \\
\hline & Units: $* *$ undefined $* *$ \\
\hline \multirow[t]{2}{*}{41} & $\begin{array}{l}\text { Payments=IF THEN ELSE(Budget-Number of Policemen*Aver Salary }>=0 \text {, Aver } \\
\text { Salary*Number of Policemen,0) }\end{array}$ \\
\hline & Units: **undefined $* *$ \\
\hline \multirow[t]{2}{*}{42} & Personal Expenses $=40+\operatorname{PULSE}$ TRAIN $(1,1,3,12) * \operatorname{RANDOM} \operatorname{UNIFORM}(0,210,1)$ \\
\hline & Units: **undefined** \\
\hline \multirow[t]{2}{*}{43} & Policemen as Permanent Department Staff $=0$ \\
\hline & Units: **undefined** $[0,40000,1]$ \\
\hline \multirow[t]{2}{*}{44} & $\begin{array}{l}\text { Policemen Available For Patrols=Policemen Available For Patrols=Number of } \\
\text { Policemen-(Policemen as Permanent Department Staff+"Policemen for Sensitive Targets } \\
\text { (VIP)"+"Policemen for Sports/Demonstrations (per Month)") }\end{array}$ \\
\hline & Units: **undefined $* *$ \\
\hline \multirow[t]{2}{*}{45} & $\begin{array}{l}\text { Policemen Efficiency=IF THEN ELSE }(((\text { Aver } \\
\text { Salary/2300)+(Entertainment/400)+(Personal Expenses/200)+Family Happiness+(Bank } \\
\text { Account/5000))/5>0, }((\text { Aver Salary/2300)+(Entertainment/400)+(Personal } \\
\text { Expenses/200)+Family Happiness+(Bank Account/5000))/5, IF THEN ELSE }(((\text { Aver } \\
\text { Salary/2300)+(Entertainment/400)+(Personal Expenses/200)+Family Happiness+(Bank } \\
\text { Account/5000))/5=0, } 0.01, \text { IF THEN ELSE }(((\text { Aver Salary/2300)+ } \\
(\text { Entertainment/400)+(Personal Expenses/200)+Family Happiness+(Bank } \\
\text { Account/5000))/5>1, } 1,0.01)))\end{array}$ \\
\hline & Units: **undefined ${ }^{* *}$ \\
\hline \multirow[t]{2}{*}{46} & Policemen for Sensitive Targets (VIP) $=0$ \\
\hline & Units: **undefined $* *[0,10000,1]$ \\
\hline \multirow[t]{2}{*}{47} & $\begin{array}{l}\text { Policemen for Sports/Demonstrations (per Month)=50+PULSE TRAIN }(1,1,1,12) \\
\text { *RANDOM UNIFORM }(70,400,0.6)\end{array}$ \\
\hline & Units: **undefined $* *[?, ?, 1]$ \\
\hline 48 & Political Immorality $=0.05$ \\
\hline
\end{tabular}




\begin{tabular}{|c|c|}
\hline & Units: **undefined ${ }^{* *}[0.05,1,0.01]$ \\
\hline \multirow[t]{2}{*}{49} & Possible Additions (Per Patrol $)=5$ \\
\hline & Units: $* *$ undefined $* *[1,30,1]$ \\
\hline \multirow[t]{2}{*}{50} & Prisoned= INTEG (Imprisonments-Liberations,Prisoners Nowdays) \\
\hline & Units: **undefined $* *$ \\
\hline \multirow[t]{2}{*}{51} & Prisoners Nowdays $=9646$ \\
\hline & Units: **undefined** $[5000,9886,1]$ \\
\hline \multirow[t]{2}{*}{52} & Prisons Final Capacity $=9886$ \\
\hline & Units: $* *$ undefined $* *[0,12000,1]$ \\
\hline \multirow[t]{2}{*}{53} & $\begin{array}{l}\text { Proposal Committing Thefts/Burglaries=SIMULTANEOUS(IF THEN ELSE(Policemen } \\
\text { Efficiency<>0, ((Unemployment*"Elasticity of Court Decisions (Misdemeanors)"*Illegal } \\
\text { Immigration*Political Immorality*"Sudden Events (Holidays)")/Policemen } \\
\text { Efficiency)*1000,0),1) }\end{array}$ \\
\hline & Units: $* *$ undefined $* *$ \\
\hline \multirow[t]{2}{*}{54} & Quantity of New Cars $=0$ \\
\hline & Units: **undefined $* *[1,100,1]$ \\
\hline \multirow[t]{2}{*}{55} & Rent/Loan $($ etc $)=0$ \\
\hline & Units: $* *$ undefined $* *[0,800,10]$ \\
\hline \multirow[t]{2}{*}{56} & Salary Taxation $($ Direct Taxes $)=0.1$ \\
\hline & Units: **undefined $* *[0.05,0.5,0.01]$ \\
\hline \multirow[t]{3}{*}{57} & SAVEPER = TIME STEP \\
\hline & Units: Month $[0, ?]$ \\
\hline & The frequency with which output is stored. \\
\hline \multirow[t]{2}{*}{58} & $\begin{array}{l}\text { Saving money=IF THEN ELSE("Aver Budget (Indirect Taxes)">=0, "Aver Budget } \\
\text { (Indirect Taxes)" , } 0 \text { ) }\end{array}$ \\
\hline & Units: **undefined** \\
\hline \multirow[t]{2}{*}{59} & $\begin{array}{l}\text { Sudden Events (Holidays })=0.05+\mathrm{PULSE} \text { TRAIN }(0.5,0.5,4,12) * \operatorname{RANDOM} \\
\text { UNIFORM }(0.01,0.1,4)\end{array}$ \\
\hline & Units: **undefined ${ }^{* *}$ \\
\hline \multirow[t]{2}{*}{60} & Super Market Cost $=80$ \\
\hline & Units: **undefined $* *[80,700,10]$ \\
\hline \multirow[t]{2}{*}{61} & Tickets/Fuel=30+PULSE TRAIN $(1,1,2,12) *$ RANDOM UNIFORM $(0,170,1)$ \\
\hline & Units: **undefined $* *$ \\
\hline \multirow[t]{3}{*}{62} & TIME STEP = 1 \\
\hline & Units: Month $[0, ?]$ \\
\hline & The time step for the simulation. \\
\hline
\end{tabular}


63

Unemployment $=0.208$

Units: **undefined $* *[0.01,0.6,0.01]$

The relationship between the variables of our Mental Model is depicted by the following Causes Tree (Figure 10).

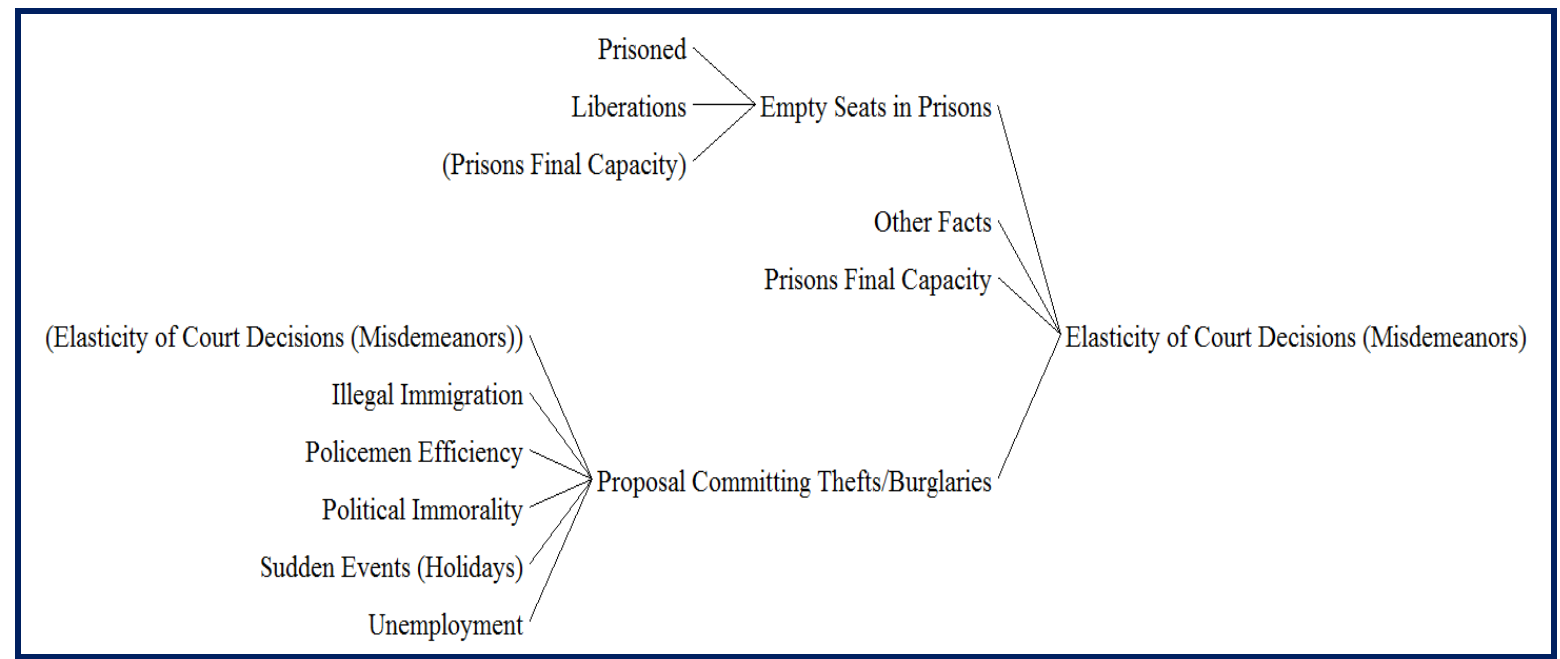

Figure 10. Mental Model Causes Tree

\section{Simulations - Examining the impact of Social Variables on Crime Rate}

When we started developing our Mental Model we established that the simulation will run twelve (12) times, one for each month of the year 2017 (Table 1). In order to evaluate whether our Mental Model extracts the data that we have actually observed in reality, we have run the simulation five (5) times and at the first simulation we have initialized the values of variables with those that we have observed in reality (Table 2).

Table 2. Mental Model Evaluation - Variables Initialization

\begin{tabular}{|c|c|c|c|}
\hline No & Views & Variables & Initial Values \\
\hline $\mathbf{1}$ & Calculate Number of Patrols & Number of Policeman & 46.500 \\
\hline $\mathbf{2}$ & Calculate Number of Patrols & $\begin{array}{c}\text { Policemen for Sensite Targets } \\
\text { (VIP) }\end{array}$ & 4.500 \\
\hline $\mathbf{3}$ & Calculate Number of Patrols & $\begin{array}{c}\text { Policemen as permanent } \\
\text { Department Staff }\end{array}$ & 33.000 \\
\hline $\mathbf{4}$ & Calculate Number of Patrols & Available Functuionally Cars & 5.000 \\
\hline $\mathbf{5}$ & Calculate Number of Patrols & Malfunctioned Cars & 125 \\
\hline $\mathbf{6}$ & Financial Annual Budget & Initial Budget & 2.606 .000 .000 \\
\hline $\mathbf{7}$ & Financial Annual Budget & Aver Price (Repairs) & 250 \\
\hline $\mathbf{8}$ & Financial Annual Budget & Aver Distance & 180 \\
\hline $\mathbf{9}$ & Financial Annual Budget & Quantity of New Cars & 0 \\
\hline
\end{tabular}




\begin{tabular}{|c|c|c|c|}
\hline $\mathbf{1 0}$ & Financial Annual Budget & Aver Price & 15.000 \\
\hline $\mathbf{1 1}$ & Financial Annual Budget & $\begin{array}{c}\text { Aver Montly Internal } \\
\text { Management }\end{array}$ & 160.000 \\
\hline $\mathbf{1 2}$ & Financial Annual Budget & Aver Salary & 1.830 \\
\hline $\mathbf{1 3}$ & Calculate Policemen Efficiency & Salary Taxation (Direct Taxes) & 0.3 \\
\hline $\mathbf{1 4}$ & Calculate Policemen Efficiency & Husband Salary & 750 \\
\hline $\mathbf{1 5}$ & Calculate Policemen Efficiency & Entertainment & 240 \\
\hline $\mathbf{1 6}$ & Calculate Policemen Efficiency & Rent/Loan (etc) & 550 \\
\hline $\mathbf{1 8}$ & Calculate Policemen Efficiency & Super Market Cost & 450 \\
\hline $\mathbf{1 9}$ & Calculate Policemen Efficiency & Extracurricular Activities & 130 \\
\hline $\mathbf{2 0}$ & Calculate Arrests \& Imprisonments & Possible Additions (Per Patrol) & 5 \\
\hline $\mathbf{2 1}$ & Calculate Arrests \& Imprisonments & Prisons Final Capacity & 9886 \\
\hline $\mathbf{2 2}$ & $\begin{array}{c}\text { Calculate Proposal Committing } \\
\text { Thefts/Burglaries }\end{array}$ & Illegal Immigration & 9646 \\
\hline $\mathbf{2 3}$ & $\begin{array}{c}\text { Calculate Proposal Committing } \\
\text { Thefts/Burglaries }\end{array}$ & Unemployment & 0.08 \\
\hline $\mathbf{2 4}$ & $\begin{array}{c}\text { Calculate Proposal Committing } \\
\text { Thefts/Burglaries }\end{array}$ & Political Immorality & 0.2028 \\
\hline
\end{tabular}

From the first simulation we found that the minimum value of the variable "Proposal Committing Thefts/Burglaries" was $5 \%$ and the maximum one was $11 \%$ (Figure 11). So the average value is at about 8\% which indicates that our model not only represents reality but has also eliminated the statistical error near to $0 \%$.

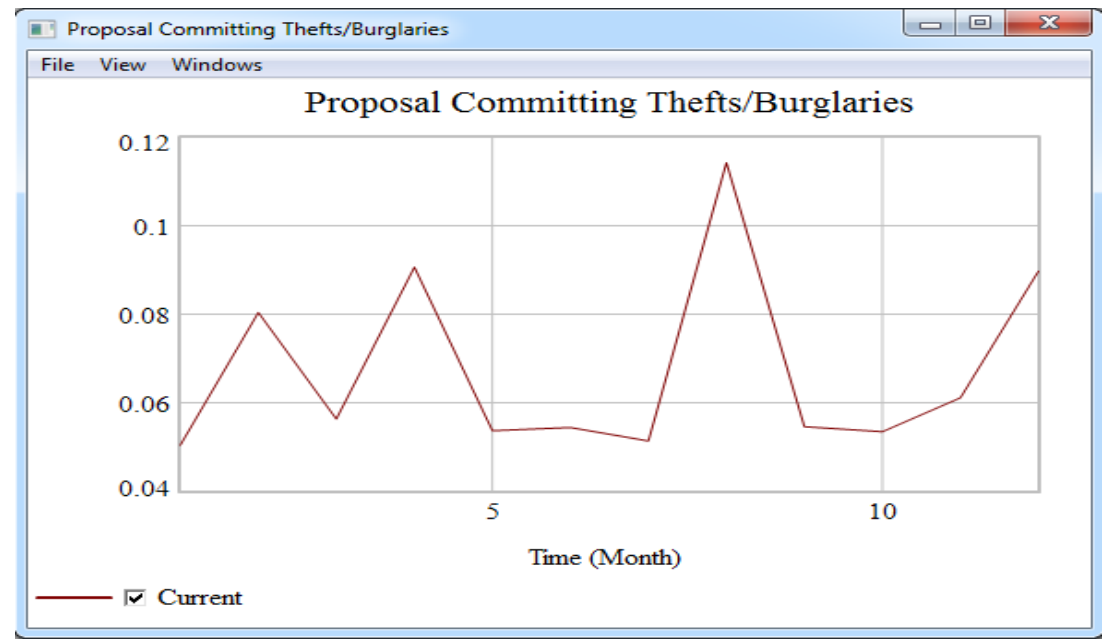

Figure 11. Evaluation - Variable "Proposal Committing Thefts/Burglaries"

At the same time the value of the variable "Elasticity of Court Decisions (Misdemeanors)" was at $80 \%$ (Figure 12) and the value of the variable "Policemen Efficiency" was at 60\% (Figure 13). 


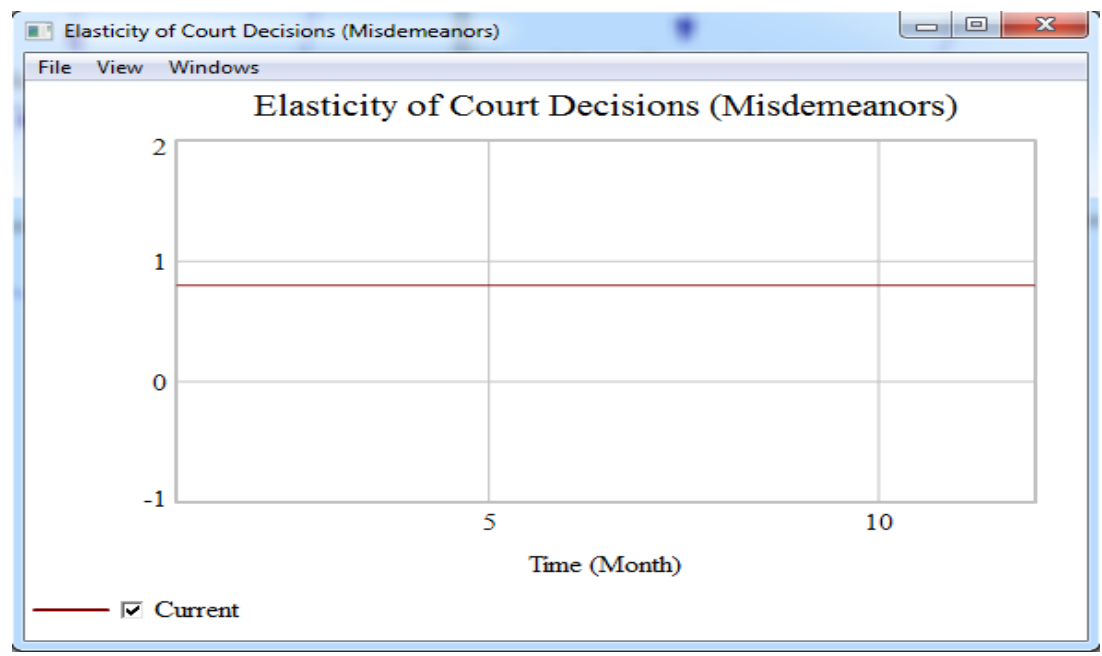

Figure 12. Evaluation - Variable "Elasticity of Court Decisions (Misdemeanors)"

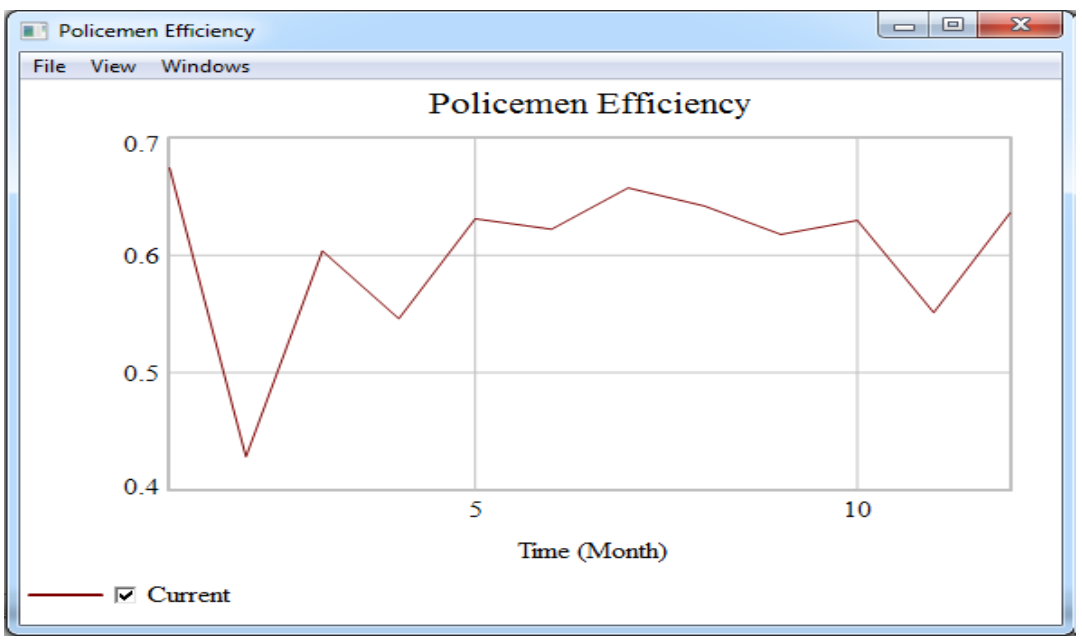

Figure 13. Evaluation - Variable "Policemen Efficiency"

At this point of our study, we understood that there was a need to repeat the simulation by altering the values of the Social Variables, in order to find out which of these contributes more to the increase of the variable "Proposal Committing Thefts/Burglaries". We conducted the simulation addressing four (4) different scenarios:

- By increasing the already Salary Taxation (Direct Taxes) by $30 \%$

- By increasing the already recorded rate of Unemployment by $30 \%$

- By increasing the already recorded Political Immorality by $50 \%$

- By increasing the already recorded Immigration by $30 \%$

For each of these scenarios we kept all the other variables untouched, in order to focus our study only on the way the variable "Proposal Committing Thefts/Burglaries" is been affected. So in the first scenario, where the "Salary Taxation" is at about 39\%, we can observe an increase of $\mathbf{0 . 5 \%}$ (Figure 14) on the value of variable "Proposal Committing Thefts/Burglaries", and at the same time we can observe a decrease on the value of variable "Policemen Efficiency" (Figure 15). 


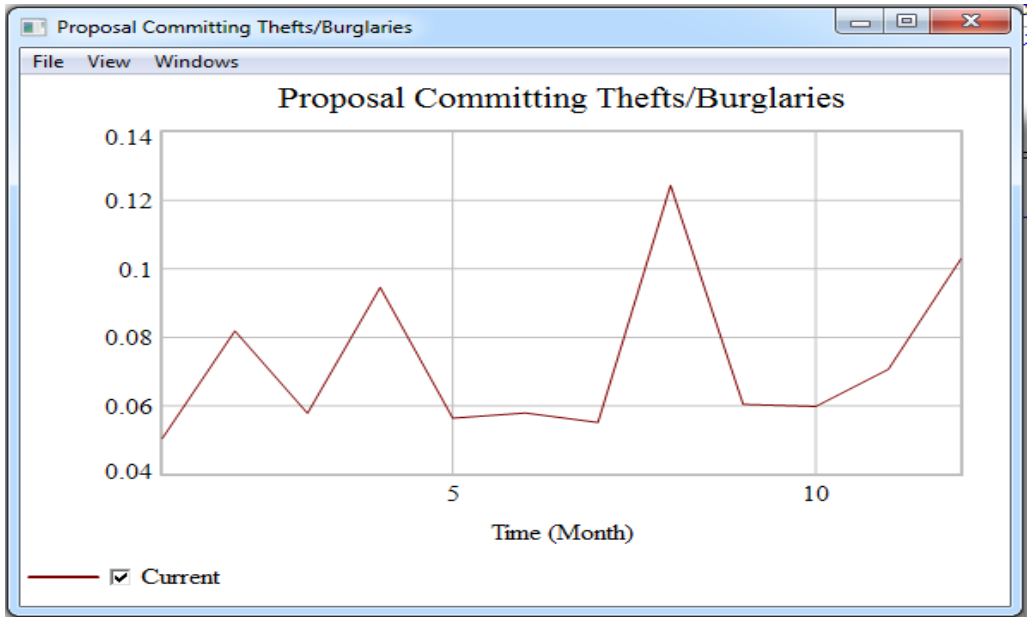

Figure 14. $1^{\text {st }}$ Scenario - Variable "Proposal Committing Thefts/Burglaries"

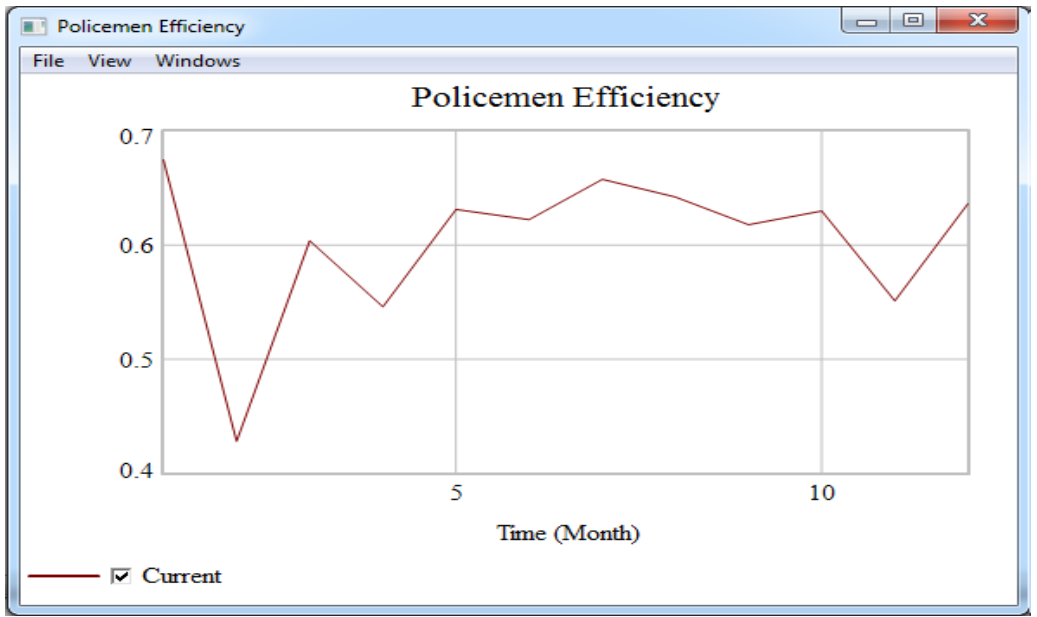

Figure 15. $1^{\text {st }}$ Scenario - Variable "Policemen Efficiency"

In the second scenario the "Unemployment" is at about $30 \%$ and we are able to observe that the value of variable "Proposal Committing Thefts/Burglaries" has been increased by 4,25\% (from $8 \%$ to $12,25 \%$ - Figure 16).

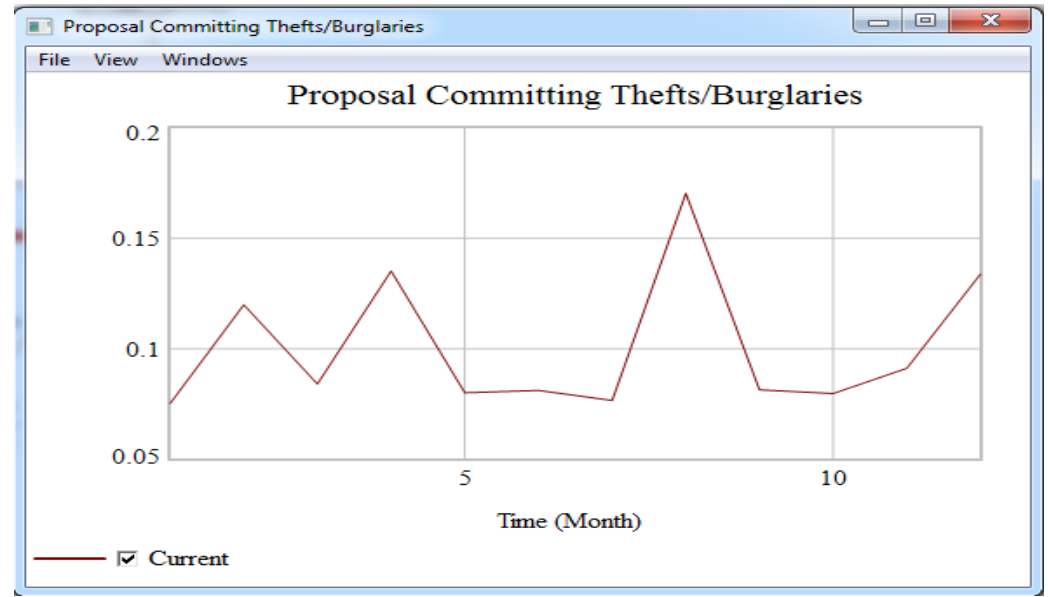

Figure 16. $2^{\text {nd }}$ Scenario - Variable "Proposal Committing Thefts/Burglaries" 
According to the next scenario the "Political Immorality" has been set to 7\% and the value of variable "Proposal Committing Thefts/Burglaries" has been changed from $8 \%$ to $11,5 \%$. So there is an increase of 3,5\% (Figure 17).

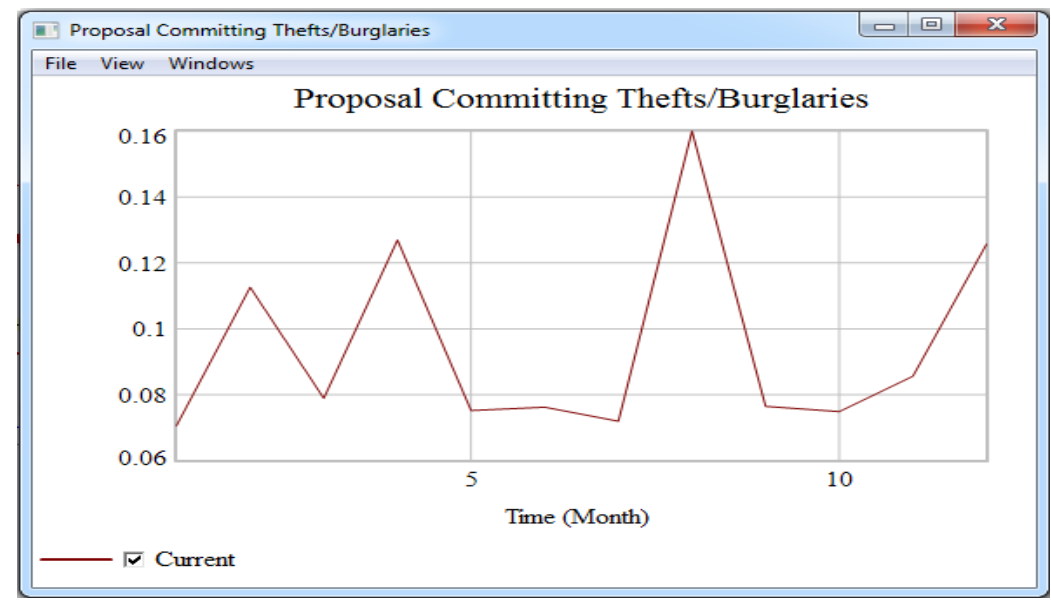

Figure 17. $3^{\text {rd }}$ Scenario - Variable "Proposal Committing Thefts/Burglaries"

In the last scenario the value of variable "Illegal Immigration" has been set to $11 \%$ from $8 \%$ and our model has found that the value of variable "Proposal Committing Thefts/Burglaries" has been increased at about $3 \%$, because from $8 \%$ has raised to $11 \%$ (Figure 18).

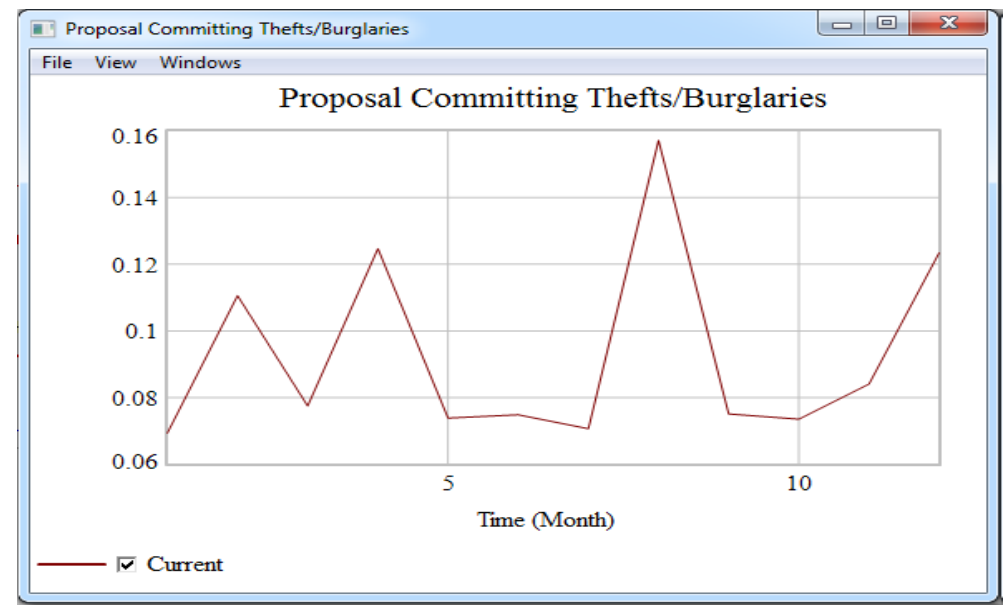

Figure 18. $3^{\text {rd }}$ Scenario - Variable "Proposal Committing Thefts/Burglaries"

\section{Practical considerations - Implementation}

The Mental Model that we have developed, projects a thorough examination of specific factors which can affect the increase or the decrease of the Crime Rate and the civilians Security Sensation. The approach as illustrated in Figures 5,6,7,8 and 9 may be helpful in understanding the way of thinking, either of the criminals, or of people who are desperate due to Economic Crisis.

In order to present the consequences of this Crisis we have examined some of these factors, as it was impossible to study all the factors that may affect the Crime Rate, because for each new factor the complexity of our study was growing exponentially. We have also considered these factors to be called as "Social Variables" and we have examined: (1) the Unemployment, (2) the Political Corruption, (3) the Immigration and (4) the Salary Taxation. Although only some of these factors 
affect the policemen's efficiency or the elasticity of court decisions in Misdemeanors, certainly all of these are affecting the human proposal to commit a Theft or a Buglary.

We have initialized the value of these factors according to measurements of: (1) the statistical office of the European Union (Eurostat), (2) the Greek Statistical Authority and (3) the Greek Police Statistical office. We observed that the model presents the reality and we have just drawn a step further on our study in order to trace the factor(s) that affect more the Crime Rate. Based on the four (4) simulations' results, we have found that when we increased by $\mathbf{3 0 \%}$ the already recorded rate of Salary Taxation (Direct Taxes) or the recorded rate of Unemployment or the recorded rate of Immigration, there was an increase of $0.5 \%$ or $4,25 \%$ or $3 \%$ respectively, for the value of variable "Proposal Committing Thefts/Burglaries". From those data we can firmly assume that the most detrimental factor is the Unemployment. At the same time the «Policemen's Efficiency" was affected one way or another, fact that is inversely proportional with the Security Sensation of the citizens. Although we have tested another simulation, in which we have increased by 50\% the recorded rate of Political Immorality, there was a 3,5\% increase of the value of variable "Proposal Committing Thefts/Burglaries", which indicates that it can't affect the variable "Proposal Committing Thefts/Burglaries", such as the Unemployment.

In each case the most detrimental factor is the Unemployment, but if it is combined with other Social Variables then the effectiveness will be higher on the variable "Proposal Committing Thefts/Burglaries".

All the facts that we have studied consist of problems existing in modern European and non-European societies. The aforementioned factors must be taken into account when the European Leaders are developing their policies on how to tackle violence and crime. Of course our Montel Model can be updated by studying other "Social Variables", either adding on the original or combined with the variable that we have already mentioned. Nevertheless its present form can be a starting point for developing more effective Action Plans/Strategies against crime.

\section{CONCLUSION}

In this study we attempted to model the way the proposal of committing specific crimes, like thefts and burglaries, increases or decreases. We started considering that the problem of continuous increase of criminality is a complicated fact and we reduced the complexity by studying specific factors that have negative effects on criminality. Our Dynamic Hypothesis was that the most effective factor on Crime Rate is going to be the Unemployment. Our reasoning was based on the fact that when the Economic Crises stroke Greece, in 2009 approximately, we started observing changes on greek citizens' behavior.

The application field for our study was the Greek commmunity as an essential part of the European Union. We studied the way the proposal of committing a theft or a burglary increses or decreases upon factors like: (1) the increase of Greek Unemployment due to the bankruptcy of many businesses and the loss of jobs, (2) the high Taxation on the Salary of civil servants and more specifically, on police officers, (3) the Illegal Immigration and how it affects the Xenophobia feeling of Greek citizens and (4) finally how recorded cases of Political Immorality, such as the bribery and the mistreatment of public money, can affect the civilians proposal of committing crimes, for which the penalty accounts for six (6) months to two (2) years.

Finally, a pilot simulation of our model was applied in order to evaluate its' correctness and then a more thorough study has justified that our Dynamic Hypothesis was also correct. The proposed Mental Model is a demo, which indicates the way that "Social Variables" affect Crime Rate and it is designed to be put in action on European Countries that are being struck by the Economic Crisis. It could consist of not only a part of a more in-depth study, in order to develop a more efficient strategy for dealing with violence and crime, but also a possible part of a "Disaster Recovery \& Continuity Plan". 


\section{RÉFÉRENCES}

Senge, P. M. (2006). The fifth discipline: The art and practice of the learning organization. Doubleday Currency, New York, NY, USA.

Rosalind Armson (2011). Growing Wings on the Way: Systems Thinking for Messy Situations by Rosalind Armson, Triarchy Press.

Bertalanffy, L. von (1968). General System Theory: Foundations, Development, Applications. George Braziller, Inc., New York, NY, USA.

Langefors, B., (1995). Essays in Infology: Summing Up and Planning for the Future, Studentlitteratur, Lund.

Richard Heinberg (2018). Systems Thinking, Critical Thinking, and Personal Resilience, Resilience.org

Ministry of Civil Protection. (2018). Statistics 2017. Retrieved from www.astynomia.gr/ images/stories/2017/statistics17/2017_1.xls

Ministry of Civil Protection. (2018). Statistics 2017. Retrieved from www.astynomia.gr/ images/stories/2017/statistics17/2017_2.xls

Georgakopoulos.org. (2018, April 04). Does the Crime Rate increases in Greece? Retrieved from https://www.georgakopoulos.org/2018/04/crime_data/

Dikaiologitika News. (2019, November 29). Wage cuts in the Public and Special Salaries. Retrieved from https://www.dikaiologitika.gr/eidhseis/ergasiaka/184298/meioseis-misthon-sto-dimosio-kai-staeidika-misthologia

Taxheaven Article. (2013, January 04). Table of minimum wage and salary ranges from 12.11.2012, according to Law 4093/2012. Retrieved from https://www.taxheaven.gr/laws/circular/view/id/15303

Greek Statistical Authority. (2018, April 12). Press Release. Retrieved from http://www.statistics.gr/documents/20181/88050d32-f39e-49e5-a2cf-f5f33f54cf02

Eurostat. (2017, January 1). File:Share of non-nationals in the resident population. Retrieved from https://ec.europa.eu/eurostat/statistics-explained/index.php?title=File:Share_of_non-nationals_in_the_ resident_population,_1_January_2016_(\%25).png

Crhnet . (2018, April 12). System Dynamics Modelling applied to Disaster Management. Retrieved from https://www.crhnet.ca/sites/default/files/library/T4A_de_smet.pdf 
